\title{
Effects of media components and agricultural by-products on p-polyglutamic acid production by Bacillus toyonensis As8
}

\author{
Olubusola A. Odeniyi ${ }^{A-F}$, David S. Avoseh ${ }^{B-F}$ \\ University of Ibadan, Nigeria \\ A - research concept and design; $\mathrm{B}$ - collection and/or assembly of data; $\mathrm{C}$ - data analysis and interpretation; \\ $\mathrm{D}$ - writing the article; $\mathrm{E}$ - critical revision of the article; $\mathrm{F}$ - final approval of the article
}

Address for correspondence

Olubusola A. Odeniyi

E-mail: busolaodeniyi@gmail.com

Funding sources

None declared

Conflict of interest

None declared

Received on August 31, 2018

Reviewed on February 4, 2019

Accepted on March 12, 2019

Cite as

Odeniyi OA, Avoseh DS. Effects of media components and agricultural by-products on $\gamma$-polyglutamic acid production by Bacillus toyonensis As8. Polim Med. 2018;48(2):91-97. doi:10.17219/pim/105555

D0I

10.17219/pim/105555

Copyright

○ 2019 by Wroclaw Medical University

This is an article distributed under the terms of the

Creative Commons Attribution 3.0 Unported (CC BY 3.0)

(https://creativecommons.org/licenses/by/3.0/)

\section{Abstract}

Background. Poly- $y$-glutamic acid ( $y-P G A)$ provides an environmentally friendly alternative to plastic materials which have widely polluted the environment.

Objectives. The microbial production of Y-PGA, an amino acid biopolymer with glutamic acid subunits, was investigated using renewable agricultural residues in an attempt to find cheaper substitutes for conventional synthetic media components.

Material and methods. Bacteria which produce $\mathrm{Y}$-PGA were isolated through depolymerizing Coix lacryma-jobi, a cellulosic grass, and the effects of various carbon and nitrogen sources, temperature, inoculant load, incubation period, and $\mathrm{pH}$ on $\mathrm{Y}$-PGA yield were determined after submerged fermentation. Bacterial growth was measured turbidimetrically at $550 \mathrm{~nm}$. The $y$-PGA produced was characterized using Fourier transform infrared (FT-IR) spectroscopy and the polymer shape was determined using scanning electron microscopy (SEM).

Results. The best y-PGA producer was molecularly identified as Bacillus toyonensis As8. The conditions which produced the highest $\mathrm{Y}-\mathrm{PGA}$ yield were glucose, ammonium sulfate, $25^{\circ} \mathrm{C}$, a pH of 5.5 , and an incubation period of $48 \mathrm{~h}$. This bacterium yielded the most $\mathrm{Y}-\mathrm{PGA}(26.45 \mathrm{~g} / \mathrm{L})$ on cassava peels, while other agro-wastes (corn cob, sorghum leaves, Coix noir leaves, and rice bran) also supported bacterial growth with

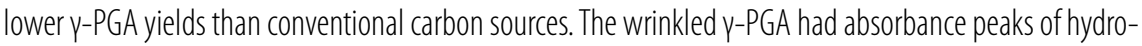
$x y l$, amide, carbonyl, and amine groups comparable with the ranges of those found in commercial $y-P G A$.

Conclusions. The use of agricultural by-products as fermentation substrates increased $y$-PGA yield and may therefore be used as substitute components in $\mathrm{Y}-\mathrm{PGA}$ production.

Key words: agricultural wastes, biopolymer synthesis, poly-y-glutamic acid characteristics, Bacillus toyonensis 


\section{Introduction}

Poly- $\gamma$-glutamic acid $(\gamma-\mathrm{PGA})$ is a non-toxic, anionic, water-soluble, and biodegradable homopolyamide consisting of $\mathrm{D}$ - and $\mathrm{L}$-glutamic acid units polymerized by $\gamma$-amide linkages and found between $\alpha$-amino and $\gamma$-carboxylic acid groups ${ }^{1-3}$ (with the molecular formula $\left.\left(\mathrm{C}_{5} \mathrm{H}_{7} \mathrm{NO}_{3}\right)_{n}\right)$. In light of the many undesirable properties associated with the use of chemically manufactured products, $\gamma$-PGA - along with many other biopolymers - has enjoyed a growing interest due to its biodegradability and non-toxicity. When compared with other production methods - such as chemical synthesis, peptide synthesis and biotransformation - microbial fermentation is considered the most cost-effective, having numerous advantages: minimal environmental pollution, potential production using inexpensive raw materials, high natural product purity, and mild reaction conditions. ${ }^{3-5}$ This important biopolymer has been found in species from all domains of life, including archaea, bacteria and eukaryotes. ${ }^{6,7}$ The traditional Japanese food natto - Bacillus subtilisfermented soybeans - contains a naturally occurring mucilaginous mixture of $\gamma$-PGA and fructan. Apart from Bacillus, many other species have been reported to produce $\gamma$-PGA, such as Planococcus, Sporosarcina, Staphylococcus, Fusobacterium, Natrialba, and Hydra $^{3-7}$ At present, microbial fermentation of biomass is still the most preferred means of commercial $\gamma$-PGA production. ${ }^{5}$

The desirable properties of $\gamma$-PGA as a safe, biodegradable, edible, eco-friendly, and water-soluble biopolymer make it and its derivatives important as food thickeners, bitterness-relieving agents, ${ }^{8}$ humectants, cryoprotectants, ${ }^{9}$ sustained-release materials, drug delivery agents, biological adhesives, heavy metal absorbers, bioflocculants, dye-removing agents, fertilizer synergists, and biodegradable plastics. Other potential applications may include its use as a contrast agent or vaccine adjuvant, or in the areas of immobilization, microencapsulation, gene delivery, and tissue engineering. ${ }^{1,8-10}$

Although the process leading to the microbial fermentative biosynthesis of $\gamma$-PGA is well-known, some challenges remain, such as the cost and suitability of substrate media for optimal yields, a fact which limits economically viable commercial applications. In addition to the important efforts currently directed at finding a lasting solution to various problems associated with $\gamma$-PGA production for commercial applications, there is a need to continue the search for potential $\gamma$-PGA producers with unique properties. In this study, the effects of media components and the suitability of agricultural byproducts as substrates for $\gamma$-PGA production in flask fermentation by various bacteria were investigated.

\section{Material and methods}

\author{
Sample collection, microorganisms \\ and screening for $\mathrm{Y}$-PGA production \\ on a solid medium
}

The Bacillus toyonensis (B. toyonensis) As8 used in this experiment was isolated from samples of decomposing Coix lacryma-jobi collected from a fallow agricultural farm of the University of Ibadan, Nigeria. The bacteria were isolated through serial dilutions of the samples ${ }^{11}$ inoculated using the pour plate method on nutrient agar and incubated at $30^{\circ} \mathrm{C}$ for $24 \mathrm{~h}$. Bacterial colonies observed on the surface of the nutrient agar were picked at random, based on differences in colonial morphology, and were streaked onto the surface of nutrient agar to obtain distinct colonies representative of a single pure isolate.

\section{Screening for $\mathrm{Y}$-PGA production}

Pure cultures of each bacterial isolate were cultivated on a solid medium composed of $1 \mathrm{~g} / \mathrm{L}$ glucose, $0.5 \mathrm{~g} / \mathrm{L}$ yeast extract, $1 \mathrm{~g} / \mathrm{L}$ L-glutamic acid, $0.05 \mathrm{~g} / \mathrm{L} \mathrm{KH}_{2} \mathrm{PO}_{4}, 0.01 \mathrm{~g} / \mathrm{L}$ $\mathrm{MgSO}_{4}$, and $15 \mathrm{~g} / \mathrm{L}$ agar $\left(\mathrm{pH} 7.0\right.$ ) at $37^{\circ} \mathrm{C}$ for $24 \mathrm{~h} .{ }^{12}$ Sticky, highly viscous colonies forming on the agar - examined for stickiness with gentle touches using a sterile inoculating needle - were considered $\gamma$-PGA-producing bacterial isolates. The isolates $(10 \% \mathrm{v} / \mathrm{v} 24$-hour-old broth culture, equivalent to $10^{8} \mathrm{CFU} / \mathrm{mL}$ ) selected from the solid screening medium as described previously were grown at $37^{\circ} \mathrm{C}$ on a shaker incubator (ZHWY211F, New Brunswick Scientific Company, New Jersey, US) at $150 \mathrm{rpm}$ for $72 \mathrm{~h}$ in a conical flask containing $100 \mathrm{~mL}$ of screening broth $\left(10 \mathrm{~g} / \mathrm{L}\right.$ L-glutamic acid, $10 \mathrm{~g} / \mathrm{L}$ glucose, $5 \mathrm{~g} / \mathrm{L}\left(\mathrm{NH}_{4}\right)_{2} \mathrm{SO}_{4}$, $1 \mathrm{~g} / \mathrm{L} \mathrm{K}_{2} \mathrm{HPO}_{4}, 1 \mathrm{~g} / \mathrm{L} \mathrm{KH}_{2} \mathrm{PO}_{4}, 0.5 \mathrm{~g} / \mathrm{L} \mathrm{MgSO} \mathrm{Mg}_{4} \cdot 7 \mathrm{H}_{2} \mathrm{O}$, $0.02 \mathrm{~g} / \mathrm{L} \mathrm{MnSO}_{4}$, and $0.05 \mathrm{~g} / \mathrm{L} \mathrm{FeCl}_{3} \cdot 7 \mathrm{H}_{2} \mathrm{O}$ ). After $72 \mathrm{~h}$ of incubation, the broth culture was centrifuged at $12,000 \mathrm{rpm}$ for $20 \mathrm{~min}$ at $4^{\circ} \mathrm{C}$ to obtain cell-free supernatants, after which an equal volume of cold ethanol was added to the supernatant to yield a fibrous precipitate regarded as the crude $\gamma$-PGA. This precipitate was concentrated with centrifugation and was subsequently oven-dried at $55^{\circ} \mathrm{C}$ to a constant weight; the weight was then measured. ${ }^{12,13}$ The best $\gamma$-PGA-producing bacteria were identified with morphological, biochemical and $16 \mathrm{~S}$ rRNA gene sequencing using universal primers. ${ }^{11,14,15}$

\section{Recovery and quantification of the produced $\gamma$-PGA}

The cells were separated from the fermentation broth with 20 min of centrifugation at $12,000 \mathrm{rpm}$ to obtain a cell-free supernatant. The $\gamma$-PGA was precipitated from the supernatant through the addition of 4 volumes of $95 \%$ ethanol with gentle stirring. The mixture was then stored 
in a refrigerator (Haier THERMOCOOL BD-124E, HPZ Nigeria) at $4^{\circ} \mathrm{C}$ for $12 \mathrm{~h}$. The resulting precipitate containing crude $\gamma$-PGA was collected using a high-speed refrigerated centrifuge (Hitachi Himae CR21GII, Hitachi Group, Tokyo, Japan) at $12,000 \mathrm{rpm}$ for $20 \mathrm{~min}$ at $10^{\circ} \mathrm{C}$. The crude $\gamma$-PGA was oven-dried at $55^{\circ} \mathrm{C}$ to a constant weight, which was then measured. ${ }^{6}$

\section{Effects of medium components and environmental conditions on $\gamma$-PGA production}

The effects of environmental conditions and the components of the medium on $\gamma$-PGA production using the selected bacterial isolates were investigated using the onefactor-at-a-time method with a PGA basal medium containing $5 \mathrm{~g} / \mathrm{L}\left(\mathrm{NH}_{4}\right)_{2} \mathrm{SO}_{4}, 1 \mathrm{~g} / \mathrm{L} \mathrm{K} \mathrm{HPO}_{4}, 1 \mathrm{~g} / \mathrm{L} \mathrm{KH}_{2} \mathrm{PO}_{4}$, $0.5 \mathrm{~g} / \mathrm{L} \mathrm{MgSO}_{4} \cdot 7 \mathrm{H}_{2} \mathrm{O}, 0.02 \mathrm{~g} / \mathrm{L} \mathrm{MnSO}_{4}$, and $0.05 \mathrm{~g} / \mathrm{L}$ $\mathrm{FeCl}_{3} \cdot 7 \mathrm{H}_{2} \mathrm{O}$. ${ }^{13}$ Variables such as the effects of different carbon sources (glucose, fructose, maltose, lactose, sucrose, citric acid, and starch) and nitrogen sources (peptone, urea, yeast extract, L-glutamic acid, ammonium sulfate, ammonium chloride, and sodium nitrate), $\mathrm{pH}$ (4.5 to 9.0 in $0.1 \mathrm{M}$ phosphate buffers), incubation temperature $\left(25^{\circ} \mathrm{C}, 30^{\circ} \mathrm{C}, 35^{\circ} \mathrm{C}, 40^{\circ} \mathrm{C}\right.$, and $\left.45^{\circ} \mathrm{C}\right)$, different inoculant loads ( $1 \%$ and $10 \%)$, and incubation period (24-96 h) on the production medium were investigated in order to determine the ones which are most conducive to $\gamma$-PGA production. To measure the effects of the different carbon sources, the basal medium contained $20 \mathrm{~g} / \mathrm{L} \mathrm{L-glutamic}$ acid, $10 \mathrm{~g} / \mathrm{L}\left(\mathrm{NH}_{4}\right)_{2} \mathrm{SO}_{4}, 1 \mathrm{~g} / \mathrm{L} \mathrm{K}_{2} \mathrm{HPO}_{4}, 1 \mathrm{~g} / \mathrm{L} \mathrm{KH}_{2} \mathrm{PO}_{4}$, $0.5 \mathrm{~g} / \mathrm{L} \mathrm{MgSO}_{4} \cdot 7 \mathrm{H}_{2} \mathrm{O}, 0.02 \mathrm{~g} / \mathrm{L} \mathrm{MnSO}_{4}$, and $0.05 \mathrm{~g} / \mathrm{L}$ $\mathrm{FeCl}_{3} \cdot 7 \mathrm{H}_{2} \mathrm{O}$. The L-glutamic acid was then substituted for each of the sugars listed above. Likewise, to test the effects of nitrogen sources, the basal medium contained $20 \mathrm{~g} / \mathrm{L}$ glucose, $10 \mathrm{~g} / \mathrm{L}\left(\mathrm{NH}_{4}\right)_{2} \mathrm{SO}_{4}, 1 \mathrm{~g} / \mathrm{L} \mathrm{K} \mathrm{HPO}_{4}, 1 \mathrm{~g} / \mathrm{L}$ $\mathrm{KH}_{2} \mathrm{PO}_{4}, 0.5 \mathrm{~g} / \mathrm{L} \mathrm{MgSO}_{4} \cdot 7 \mathrm{H}_{2} \mathrm{O}, 0.02 \mathrm{~g} / \mathrm{L} \mathrm{MnSO}_{4}$, and $0.05 \mathrm{~g} / \mathrm{L} \mathrm{FeCl} \cdot 7 \mathrm{H}_{2} \mathrm{O} ;\left(\mathrm{NH}_{4}\right)_{2} \mathrm{SO}_{4}$ was then substituted for the other nitrogen sources.

To measure the effects of $\mathrm{pH}$, incubation temperature and incubation period, the basal medium consisted of $20 \mathrm{~g} / \mathrm{L} \mathrm{L}$-glutamic acid, $20 \mathrm{~g} / \mathrm{L}$ glucose, $10 \mathrm{~g} / \mathrm{L}\left(\mathrm{NH}_{4}\right)_{2} \mathrm{SO}_{4}$,

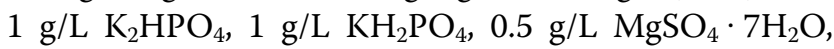
$0.02 \mathrm{~g} / \mathrm{L} \mathrm{MnSO}_{4}$, and $0.05 \mathrm{~g} / \mathrm{L} \mathrm{FeCl}_{3} \cdot 7 \mathrm{H}_{2} \mathrm{O} .{ }^{13}$ A loopful of 18-24-hour-old nutrient agar culture of the $\gamma$-PGAproducing bacterium was transferred into the PGA broth and incubated at $35^{\circ} \mathrm{C}$ for $24 \mathrm{~h}$. A $10 \% \mathrm{v} / \mathrm{v}$ dilution of this preparation was used as an inoculant for the experiments. The fermentation flasks were incubated with agitation at $150 \mathrm{rpm}$ over 4 days. Bacterial growth was determined with optical density using a Jenway 6405 UV-VIS spectrophotometer (Cole-Parmer, UK) at $550 \mathrm{~nm}$. ${ }^{6,16}$

The effects of different agricultural wastes (corn cob, sorghum leaves, Coix noir leaves, cassava peel, and rice bran) as carbon sources for $\gamma$-PGA production by the selected $\gamma$-PGA producers were investigated. Freshly collected agricultural wastes were oven-dried at $45^{\circ} \mathrm{C}$, pulverized and sieved to obtain powder-sized particles. Each of these substrates $(20 \mathrm{~g} / \mathrm{L})$ was added into the $\gamma$-PGA production medium as the major source of carbon and autoclaved at $121^{\circ} \mathrm{C}$ for $15 \mathrm{~min}$, after which they were allowed to cool to room temperature and were inoculated as described previously. They were then incubated at $35^{\circ} \mathrm{C}$ on a shaker incubator (ZHWY211F, New Brunswick Scientific Company, New Jersey, US) at $150 \mathrm{rpm}$ for $72 \mathrm{~h}$. At the end of the incubation, the fermentation broth was diluted with an equal volume of sterile distilled water and centrifuged using the refrigerated centrifuge at $12,000 \mathrm{rpm}$ for $20 \mathrm{~min}$ to recover the $\gamma$-PGA; the yield was then measured. ${ }^{6,16}$ The best environmental variables and agricultural wastes for the highest $\gamma$-PGA yield in these experiments were used to produce $\gamma$-PGA.

In all cases, the means of triplicate experimental readings were used.

\section{Characteristics of $\mathrm{Y}-\mathrm{PGA}$}

The peaks of the spectra of key functional groups in the $\gamma$-PGA produced in the experiments were identified using Fourier transform infrared (FT-IR) spectroscopy. Their absorption spectra, with peaks corresponding to specific bonds in the $\gamma$-PGA product, were compared with standards characteristic of amine $(\mathrm{C}-\mathrm{N})$, carbonyl $(\mathrm{C}=\mathrm{O})$, amide $(\mathrm{N}-\mathrm{H})$, and hydroxyl $(\mathrm{OH})$ groups in the ranges of $1085-1165 \mathrm{~cm}^{-1}$, $1394-1454 \mathrm{~cm}^{-1}, 1620-1655 \mathrm{~cm}^{-1}$, and $3400-3450 \mathrm{~cm}^{-1}$, respectively. ${ }^{17,18}$ Scanning electron microscopy (SEM) was also used to determine the surface morphology of the polymer produced. An FEI Inspect S50 scanning electron microscope (FEI Company, Japan) with an acceleration voltage of $10 \mathrm{kV}$ was used. The polymer samples were placed on a metallic stub and sputtered with gold film under vacuum; images were taken at different levels of magnification.

\section{Results and discussion}

\section{Screening of isolates for $\mathrm{Y}$-PGA production}

Approximately $14 \%$ of the 36 isolates obtained from the decomposing Coix lacryma-jobi (As8, Is6, Is7, Is13, and Is14) produced viscous colonies when screened. The highest yield from the submerged fermentation, $16.53 \mathrm{~g} / \mathrm{L}$ of $\gamma$-PGA, was recovered from the As8 fermentation culture. This was followed by isolates Is14, Is6, Is7, and Is13 with $\gamma$-PGA yields of $14.82 \mathrm{~g} / \mathrm{L}, 14.07 \mathrm{~g} / \mathrm{L}, 12.58 \mathrm{~g} / \mathrm{L}$, and $9.42 \mathrm{~g} / \mathrm{L}$, respectively. The $5 \gamma$-PGA-positive isolates were Gram-positive, facultative, anaerobic spore formers and were presumptively identified as Bacillus species (Table 1). Phenotypic and biochemical techniques have been successfully used in the past to identify different microorganisms in microbiology. ${ }^{16}$ Isolate As8, the most prolific $\gamma$-PGA producer, was capable of metabolizing different 
Table 1. Morphological and biochemical characteristics of poly- $\gamma$-glutamic-acid ( $\gamma$-PGA)-producing bacteria

\begin{tabular}{|c|c|c|c|c|c|}
\hline Y-PGA-producing isolates & As8 & Is6 & Is7 & Is13 & Is14 \\
\hline Gram's reaction & + & + & + & + & + \\
\hline Morphology & short rods & rods & rods & rods & rods \\
\hline Endospore staining & + & + & + & + & + \\
\hline Gelatin hydrolysis & + & + & + & + & + \\
\hline Starch hydrolysis & + & + & + & + & + \\
\hline Proteolysis & + & + & + & + & + \\
\hline Hemolysis & + & - & - & - & - \\
\hline Lecithinase test & + & - & + & - & + \\
\hline Catalase test & + & + & + & + & + \\
\hline Citrate utilization & + & + & - & + & + \\
\hline Methyl red test & - & - & - & - & - \\
\hline Voges-Proskauer test & + & + & + & + & + \\
\hline Glucose & + & - & + & - & + \\
\hline Fructose & + & $+/-$ & + & - & + \\
\hline Lactose & - & - & - & + & + \\
\hline Maltose & + & $+/-$ & - & $+/-$ & + \\
\hline Sucrose & + & - & - & + & + \\
\hline Galactose & - & - & $+/-$ & - & + \\
\hline Raffinose & - & + & - & - & $+/-$ \\
\hline Probable identity of the organism & Bacillus sp. As8 & Bacillus sp. Is6 & Bacillus sp. Is7 & Bacillus sp. Is13 & Bacillus sp. Is 14 \\
\hline
\end{tabular}

(+) - positive; (-) - negative; (+/-) - variable.

sugars (such as glucose, fructose and maltose) and tested positive for utilizing catalase, protease, lecithinase, and citrate, as well as for starch hydrolysis and gelatin hydrolysis. The isolate As8, however, did not metabolize lactose, galactose or raffinose. Genotypically, Bacillus sp. As8 was 96\% percent similar to the B. toyonensis strain BCT-7112 and was therefore referred to as B. toyonensis As8.

\section{Growth and $\gamma$-PGA production responses of Bacillus toyonensis As8 to physicochemical modifications of medium components}

Bacillus toyonensis As8 (the representative colony depicted in Fig. 1A) had the highest $\gamma$-PGA yield $(16.53 \mathrm{~g} / \mathrm{L})$ with glucose and fructose as carbon sources, while its yield in a starch-based medium was the lowest $(4.06 \mathrm{~g} / \mathrm{L})$ - even though that substrate was highly conducive to bacterial growth (Fig. 1B). All of the sugars used as carbon sources supported bacterial growth. These findings may be attributed to the fact that simple sugars are more desirable for bacterial metabolism since less energy is required to incorporate them into the metabolism of a cell. However, Ju et al. ${ }^{19}$ obtained a higher $\gamma$-PGA yield with $30 \mathrm{~g} / \mathrm{L}$ of starch in the fermentation medium and B. subtilis MJ80, yielding $48.3 \mathrm{~g} / \mathrm{L}$ of $\gamma$-PGA. The findings that citric acid and starch supported bacterial growth may be attributed to the ease with which these compounds convert into glutamic acids, through the tricarboxylic acid cycle and finally into poly- $\gamma$-glutamate..$^{20}$
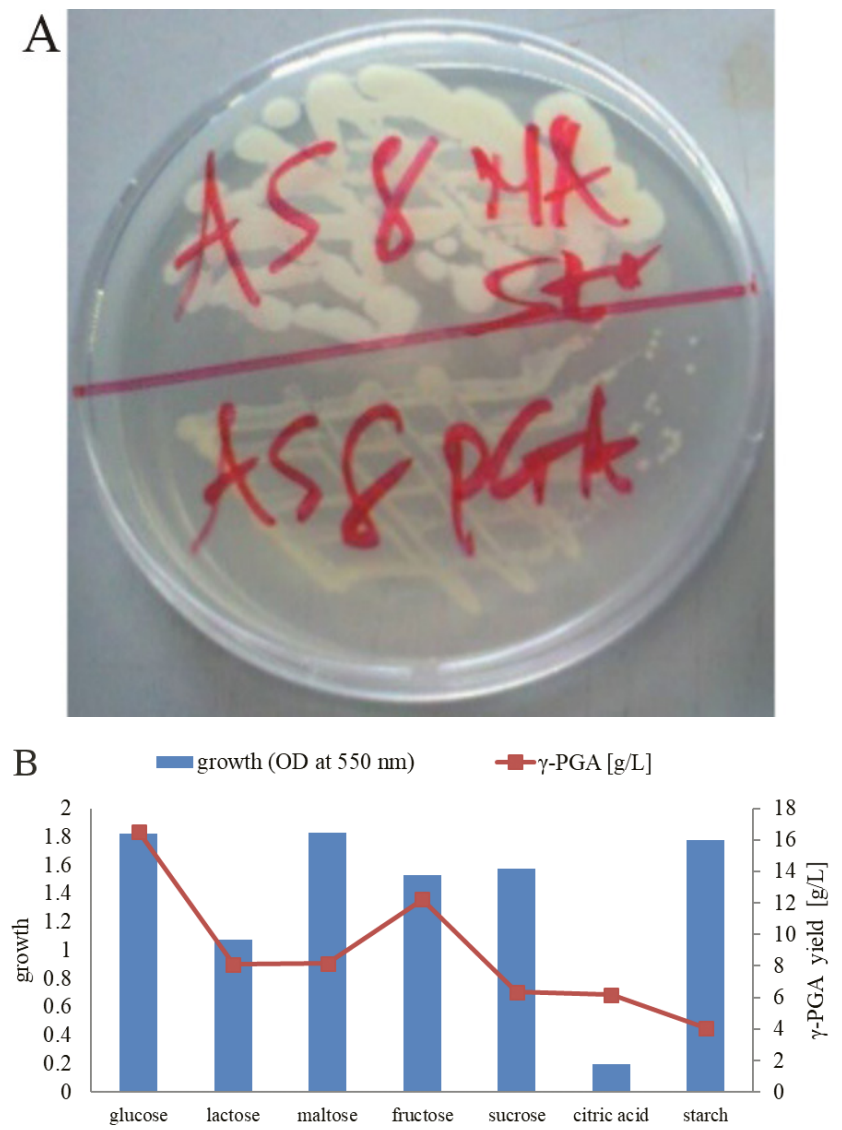

Fig. 1. (A) Colonial view of Bacillus toyonensis As8. (B) Effect of different carbon sources on the growth and poly- $\gamma$-glutamic-acid ( $\gamma-P G A)$ yield of Bacillus toyonensis As8 
Ammonium sulfate supported both bacterial growth (optical density: 1.854) and $\gamma$-PGA production (19.95 g/L) by B. toyonensis As8 (Fig. 2). Organic peptone and malt extract did support $\gamma$-PGA production, though less so than inorganic ammonium sulfate. Because $\gamma$-PGA was produced in the medium containing ammonium sulfate in the absence of L-glutamic acid, we may deduce that B. toyonensis As8 can be classified as an L-glutamic acidindependent $\gamma$-PGA-producing strain. ${ }^{3}$

There was a progressive reduction in $\gamma$-PGA yield as the incubation temperature increased (Fig. 3), indicating that the $\gamma$-PGA yield from $B$. toyonensis As8 was temperaturedependent. ${ }^{16}$ Production was highest at $25^{\circ} \mathrm{C}$, with a dry weight of $18.25 \mathrm{~g} / \mathrm{L}$. The lowest yield of $6.10 \mathrm{~g} / \mathrm{L}$ was observed at $45^{\circ} \mathrm{C}$, at which temperature the $\gamma$-PGA producer exhibited the highest turbidimetric reading. In a related study, the optimal growth temperature for Bacillus licheniformis NRC20 was reported to be $30^{\circ} \mathrm{C}$, while the highest $\gamma$-PGA yield was obtained at $35^{\circ} \mathrm{C} .{ }^{16,21}$

From Fig. 4, while the lowest $\gamma$-PGA production was recorded at an acidic $\mathrm{pH}(4.5)$, the highest was at $\mathrm{pH} 5.5$ $(26 \mathrm{~g} / \mathrm{L})$. At neutral $\mathrm{pH}$ and above, the $\gamma$-PGA yield was reduced to about $64 \%$ of the highest yield though the bacterial growth was highest. The highest fermentative production of $\gamma$-PGA was reported at a $\mathrm{pH}$ of $6.5 .^{22}$ The level of $\mathrm{pH}$ significantly affects bacterial nutrient solubility and uptake, enzyme activity, and cell membrane morphology, thus impacting the formation of by-products $(\gamma$-PGA release). ${ }^{16}$ The fact that the highest $\gamma$-PGA yield was recorded at $\mathrm{pH} 5.5$ may indicate that this $\mathrm{pH}$ influenced microbial metabolism to favor a higher $\gamma$-PGA release.

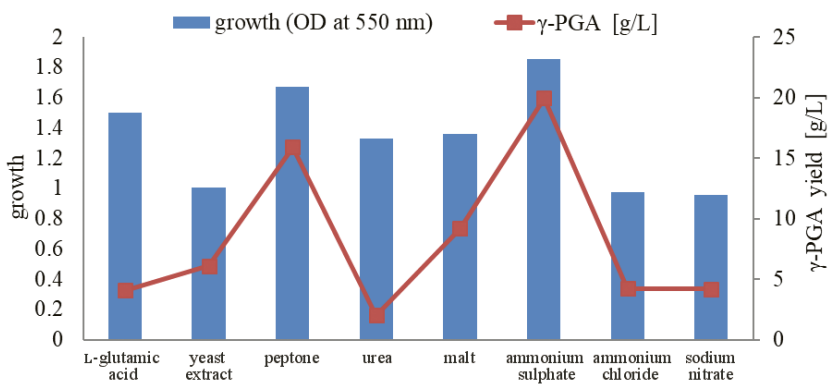

Fig. 2. Effect of different nitrogen sources on the growth and poly- $\gamma$-glutamic-acid ( $\gamma$-PGA) yield of Bacillus toyonensis As 8

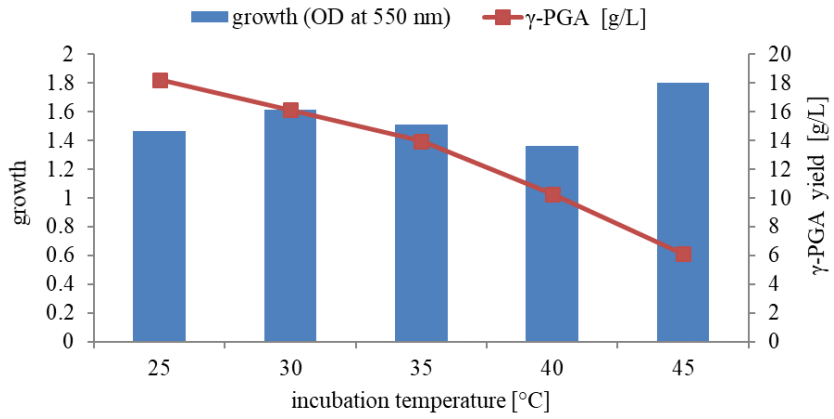

Fig. 3. Effect of incubation temperature on the growth and poly- $\gamma$-glutamic-acid ( $\gamma$-PGA) yield of Bacillus toyonensis As8

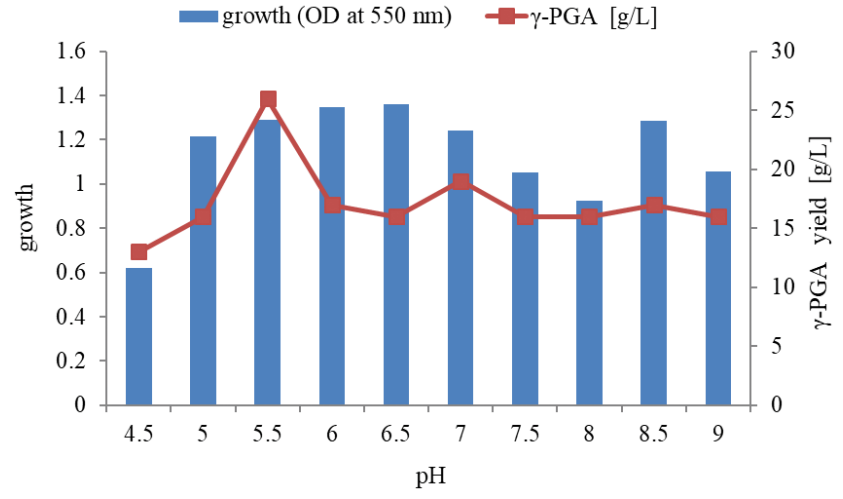

Fig. 4. Effect of $\mathrm{pH}$ on the growth and poly- $\gamma$-glutamic-acid ( $\gamma-P G A)$ production of Bacillus toyonensis As8

\section{Effects of inoculant concentration and incubation period on $\mathrm{Y}$-PGA production}

Over the $96 \mathrm{~h}$, bacterial growth increased in the 2 flask experiments. However, the highest $\gamma$-PGA yield $(23.65 \mathrm{~g} / \mathrm{L})$ was observed after $48 \mathrm{~h}$ of incubation in the production medium inoculated with $10 \%$ of B. toyonensis As8. After this, there was a progressive reduction in yield from both media (Fig. 5A,B). Ju et al. ${ }^{19}$ reported the highest $\gamma$-PGA yield by a $B$. subtilis strain at the end of a 5-day incubation before a fall in yield and concluded that - for that strain - the longer the incubation time, the higher the production of $\gamma$-PGA. There was a progressive increase in optical density proportional to increasing incubation time. It was reported that the $\gamma$-PGA product could serve as a source of glutamate for the producing
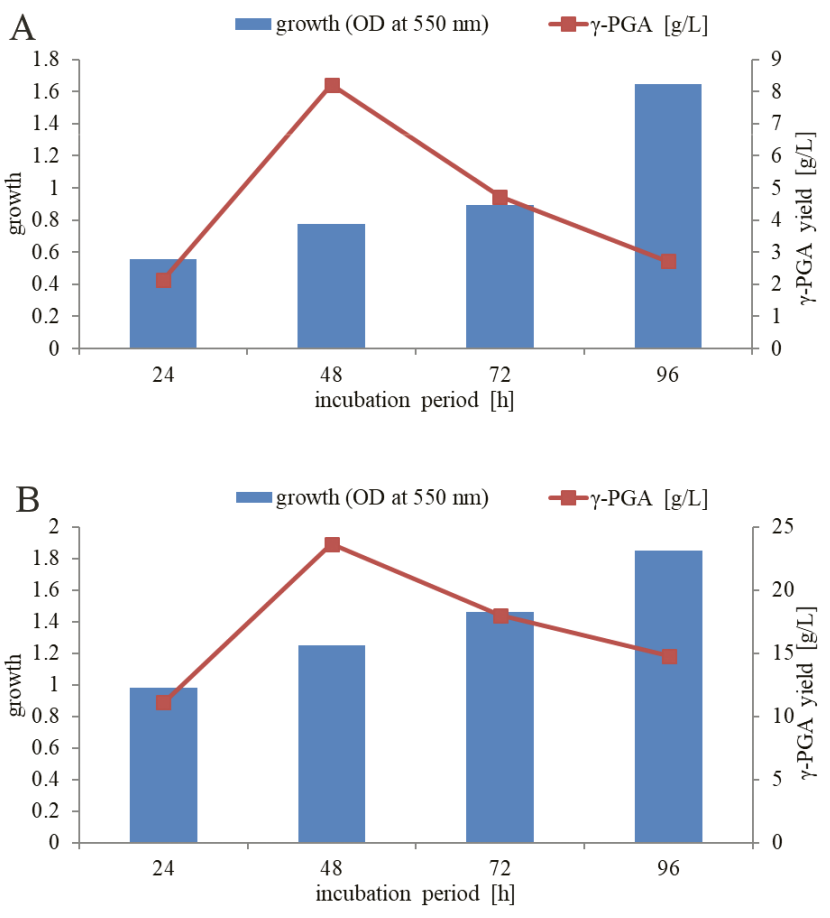

Fig. 5. Effect of (A) 1\% and (B) 10\% inoculation with different incubation periods on the growth and poly- $\gamma$-glutamic-acid ( $\gamma$-PGA) production of Bacillus toyonensis As8 
strain during its late stationary phase of life to sustain cell metabolism while nutrients and energy become limited, ${ }^{23}$ which might be the reason for the reduction in the $\gamma$-PGA recovered. This also agrees with another report that the glutamic acid product of $\gamma$-PGA degradation catalyzed by $\gamma$-glutamyl hydrolase was utilized by the bacteria as a source of carbon and nitrogen. ${ }^{24}$

\section{Y-PGA production using agricultural residues}

Many carbon- and nitrogen-based agro-industrial wastes (such as rice straw, wheat bran, corn bran, corn cob, sugarcane bagasse, cotton stalk, sorghum stover, and soybean cake) have been used as substrates in microbial fermentation because they can be biologically converted to 6-carbon and 5-carbon compounds which are funneled into the main carbon metabolism via glycolysis and the pentose phosphate pathway. ${ }^{20,25}$ Although all of the agro-substrates supported $\gamma$-PGA production, the highest yield was obtained with cassava peel $(22.26 \mathrm{~g} / \mathrm{L})$ as the sole source of carbon (Table 2), an indication that the carbohydrate it contained could easily be metabolized by B. toyonensis As8 into simpler forms for subsequent conversion into $\alpha$-ketoglutaric acid (a precursor metabolite of L-glutamine) in the citric acid cycle (TCA). There was an increase in $\gamma$-PGA production when $10 \%$ of the $\gamma$-PGA producer was cultivated under optimal culture conditions in a medium that now contained either cassava peel, fructose or Coix leaves with ammonium sulfate, at $25^{\circ} \mathrm{C}$ and a $\mathrm{pH}$ of 5.5 , over $48 \mathrm{~h}$ to yield $26.45 \mathrm{~g} / \mathrm{L}, 23.23 \mathrm{~g} / \mathrm{L}$ and $16.87 \mathrm{~g} / \mathrm{L}$ of $\gamma$-PGA, respectively.

Table 2. Effects of various agricultural wastes as carbon sources on poly- $\gamma$-glutamic-acid ( $\gamma$-PGA) production by Bacillus toyonensis As8

\begin{tabular}{lc|}
\hline \multicolumn{1}{|c|}{ Agro-waste - carbon source } & $\gamma$-PGA $[\mathrm{g} / \mathrm{L}]$ \\
\hline Corn cob & 6.03 \\
Sorghum leaves & 10.03 \\
Coix noir leaves & 8.37 \\
Cassava peels & 22.26 \\
Rice bran & 8.35 \\
\hline
\end{tabular}

\section{Characterization of the $\mathrm{Y}$-PGA produced}

Fourier transform infrared spectroscopy of the $\gamma$-PGA produced by B. toyonensis As8 revealed the key characteristic functional groups of $\gamma$-PGA (Fig. 6). The absorbance spectrum had peaks ranging from $441.26 \mathrm{~cm}^{-1}$ to $3771.78 \mathrm{~cm}^{-1}$, where functional groups including hydroxyl, amide, carbonyl, and amine groups - common features of $\gamma$-PGA - were represented. This is similar to the results obtained by Kedia et al., ${ }^{18}$ who measured over 100 scans and wavelength ranges of $400-4000 \mathrm{~cm}^{-1}$ using the same technique. The results of the present study for the $\gamma$-PGA produced by B. toyonensis As 8 - amide absorption at $1639.38 \mathrm{~cm}^{-1}$, carbonyl absorption at $1439.00 \mathrm{~cm}^{-1}$ and hydroxyl absorption at $3417.00 \mathrm{~cm}^{-1}$ - are in agreement with those of other authors ${ }^{17,19,26}$ who independently reported a strong amide $(\mathrm{N}-\mathrm{H})$ absorption at 1620-1655 $\mathrm{cm}^{-1}$, a weaker carbonyl $(\mathrm{C}=\mathrm{O})$ absorption at $~ 1394-1454 \mathrm{~cm}^{-1}$, a strong hydroxyl $(\mathrm{OH})$ absorption at $\sim 3400-3450 \mathrm{~cm}^{-1}$, and a characteristically strong amine $(\mathrm{C}-\mathrm{N})$ absorption in the range of $1085-1165 \mathrm{~cm}^{-1}$.

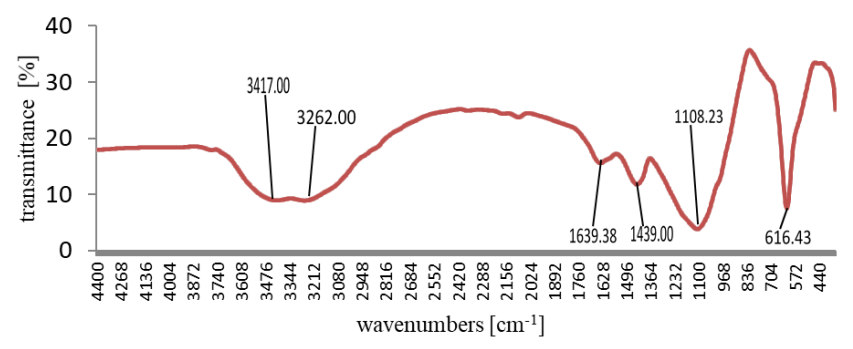

Fig. 6. FTIR Spectra of the poly- $\gamma$-glutamic-acid ( $\gamma$-PGA) produced by Bacillus toyonensis As8

Figure 7 shows the scanning electron micrograph of the $\gamma$-PGA produced by B. toyonensis As8. The polymer particles were clumped together as agglomerates and the surfaces of the agglomerates were rough, wrinkled and nonuniform, which indicates the polymeric material might be non-free-flowing, loosely packed and porous.

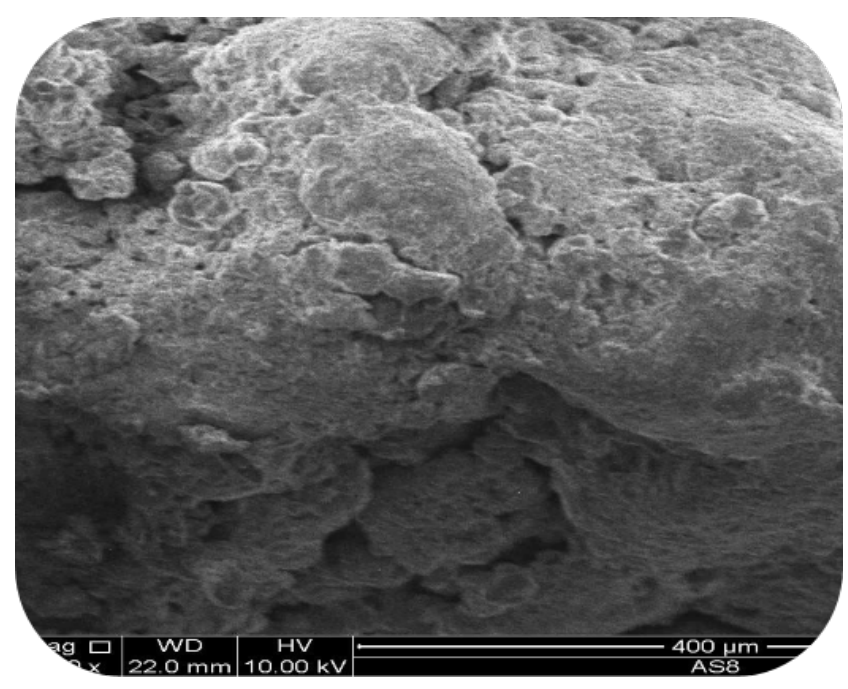

Fig. 7. Scanning electron micrograph of the poly- $\gamma$-glutamic-acid ( $\gamma$-PGA) produced by Bacillus toyonensis As 8

\section{Conclusions}

In this study, the effects of media components and various agricultural wastes as substrates for the microbial production of $\gamma$-PGA were investigated. Cassava peels as the sole source of carbon supported the highest $\gamma$-PGA yield for the non-glutamic-acid-dependent Bacillus toyonensis As8 $(26.45 \mathrm{~g} / \mathrm{L})$ at a $\mathrm{pH}$ of 5.5 and at $25^{\circ} \mathrm{C}$. 
Also, the key groups/peaks present in the product were characteristic of the $\gamma$-PGA. Although they have been used in the past as substrates due to their abundance in our environment, cassava peels and many other agricultural by-products could be harnessed as substrates for large-scale $\gamma$-PGA production in a bid to reduce the high costs associated with commercial $\gamma$-PGA production.

\section{ORCID iDs}

Olubusola A. Odeniyi (1) https://orcid.org/0000-0002-0826-791X

David S. Avoseh (1) https://orcid.org/0000-0002-0647-1546

\section{References}

1. Shih IL, Van YT. The production of poly (gamma-glutamic acid) from microorganisms and its various applications. Bioresour Technol. 2001;79(3):207-225.

2. Sung MH, Park C, Kim CJ, Poo H, Soda K, Ashiuchi M. Natural and edible biopolymer poly- $\gamma$-glutamic acid: Synthesis, production, and applications. Chem Rec. 2005;5(6):352-366.

3. Bajaj IB, Singhal RS. Poly (glutamic acid): An emerging biopolymer of commercial interest. Bioresour Technol. 2011;102(10):5551-5561.

4. Sanda F, Fujiyama T, Endo T. Chemical synthesis of poly-gammaglutamic acid by polycondensation of gamma-glutamic acid dimer: Synthesis and reaction of poly-gamma-glutamic acid methyl ester. Polym Sci Chem. 2001;39(5):732-741.

5. Ogunleye A, Bhat A, Irorere VU, Hill D, Williams C, Radecka I. Poly- $\gamma$-glutamic acid: Production, properties and applications. Microbiology. 2015;161(Pt 1):1-17.

6. Goto A, Kunioka M. Biosynthesis and hydrolysis of poly ( $\gamma$-glutamic acid) from Bacillus subtilis IFO3335. Biosci Biotechnol Biochem. 1992;56(7):1031-1035.

7. Candela T, Moya M, Haustant M, Fouet A. Fusobacterium nucleatum the first Gram-negative bacterium demonstrated to produce polyglutamate. Can J Microbiol. 2009;55(5):627-632.

8. Sakai K, Sonoda C, Murase K, inventors; Bitterness relieving agent. 2000. JP Patent WO0021390.

9. Bhat $A R$, Irorere $\mathrm{VU}$, Bartlett $\mathrm{T}$, et al. Improving survival of probiotic bacteria using bacterial poly- $\gamma$-glutamic acid. Int J Food Microbiol. 2015;196:24-31.

10. Luo Z, Guo Y, Liu J, et al. Microbial synthesis of poly- $y$-glutamic acid: Current progress, challenges, and future perspectives. Biotechnol Biofuels. 2016;9(134):1-12.

11. Olutiola PO, Famurewa O, Sonntag HG. Introduction to General Microbiology: A Practical Approach. $2^{\text {nd }}$ ed. Ikeja, Nigeria: Bolabay Publications; 2000.

12. Nagai T, Koguchi K, Itoh Y. Chemical analysis of poly- $\gamma$-glutamic acid produced by plasmid-free Bacillus subtilis (natto): Evidence that plasmids are not involved in poly- $\psi$-glutamic acid production. J Gen Appl Microbiol. 1997;43(3):139-143.

13. Kunioka M, Goto A. Biosynthesis of poly ( $\gamma$-glutamic acid) from L-glutamic acid, citric acid, and ammonium sulfate in Bacillus subtilis IFO3335. Appl Microbiol Biotechnol. 1994;40(6):867-872.

14. Fawole MO, Oso BA. Characterization of Bacteria: Laboratory Manual of Microbiology. $4^{\text {th }}$ ed. Ibadan, Nigeria: Spectrum Book Ltd; 2004.

15. Seo JH, Kim CS, Lee SP. Physicochemical properties of poly$\gamma$-glutamic acid production by a novel Bacillus subtilis HA isolated from Cheonggukjang. J Food Sci Nutr. 2008;13(4):354-361.

16. Tork SE, Aly MM, Alakilli SY, Al-Seeni MN. Purification and characterization of gamma poly glutamic acid from newly Bacillus licheniformis NRC20. Int J Biol Macromol. 2015;74:382-391.

17. Ho GH, Ho TI, Hsieh KH, et al. $\gamma$-Polyglutamic acid produced by Bacillus subtilis (natto): Structural characteristics, chemical properties and biological functionalities. J Chinese Chem Soc Taipei. 2006;53(6):1363-1384.

18. Kedia G, Hill D, Hill R, Radecka I. Production of poly-glutamic acid by Bacillus subtilis and Bacillus licheniformis with different growth media. J Nanosci Nanotechnol. 2010;10(9):5926-5934.
19. Ju WT, Song YS, Jung WJ, Park RD. Enhanced production of poly- $\gamma$ glutamic acid by a newly-isolated Bacillus subtilis. Biotechnol Lett. 2014;36(11):2319-2324.

20. Peng Y, Zhang T, Mu W, Miao M, Jiang B. Intracellular synthesis of glutamic acid in Bacillus methylotrophicus SK19.001, a glutamate independent poly ( $\gamma$-glutamic acid)-producing strain. J Sci Food Agric. 2016;96(1):66-72.

21. Du G, Yang G, Qu Y, Chen J, Lun S. Effects of glycerol on the production of poly ( $\gamma$-glutamic acid) by Bacillus licheniformis. Process Biochemistry. 2005;40(6):2143-2147.

22. Shih IL, Van YT, Chang YN. Application of statistical experimental methods to optimize production of poly( $\gamma$-glutamic acid) by Bacillus licheniformis CCRC 12826. Enzyme and Microbial Technology. 2002;31(3):213-220.

23. Hezayen FF, Rehm BHA, Eberhardt R, Steinbuchel A. Polymer production by two newly isolated extremely halophilic Archaea: Application of a novel corrosion-resistant bioreactor. Appl Microbiol Biotechnol. 2000;54(3):319-325.

24. Kimura K, Tran LSP, Uchida I, Itoh Y. Characterization of Bacillus subtilis $\gamma$-glutamyltransferase and its involvement in the degradation of capsule poly- $\gamma$-glutamate. Microbiology. 2004;150(Pt 12):4115-4123.

25. Odeniyi OA, Adeola OJ. Production and characterization of polyhydroxyalkanoic acid from Bacillus thuringiensis using different carbon substrates. Int J Biol Macromol. 2017;104(Pt A):407-413.

26. Bhat AR, Irorere VU, Bartlett $\mathrm{T}$, et al. Bacillus subtilis natto: A nontoxic source of poly- $\gamma$-glutamic acid that could be used as a cryoprotectant for probiotic bacteria. AMB Express. 2013;3(36):1-9. 